\title{
Development of professional thinking in the setting of group multimodal supervision
}

\author{
Superwizja grupowa w modelu multimodalnym jako narzędzie \\ doskonalenia umiejętności profesjonalnego myślenia
}

\author{
1 Professional League of Psychologists and Specialists of Helping Professions, Almaty, Republic of Kazakhstan \\ ${ }^{2}$ Al-Farabi Kazakh National University, Almaty, Republic of Kazakhstan \\ ${ }^{3}$ Turan University, Almaty, Republic of Kazakhstan \\ ${ }^{4}$ Kazakh National Women's Teacher Training University, Almaty, Republic of Kazakhstan \\ ${ }^{5}$ National School of Public Policy, Academy of Public Administration under the President of the Republic Kazakhstan, Nur-Sultan, Republic of Kazakhstan \\ Correspondence: Sveta Berdibayeva, Al-Farabi Kazakh National University, 050038, Kazakhstan, Almaty, Al-Farabi Avenue 71, tel.: +7 777 2374977, e-mail: kubieva.sv@gmail.com
}

Abstract The aims of this article are multifaceted: to change the ideas about the traumatic nature of supervision, to reveal its potential in the development of young specialists, to preserve and maintain professional identity among experienced psychologists, and to develop supervision as an integral part of the full-fledged activity of practising psychologists and specialists in the helping professions in Kazakhstan. The article is devoted to the analysis of the main definitions of professional thinking which are developing in the setting of group multimodal supervision. Based on the analysis, three definitions were identified - the unity of affect and intelligence, theoretical thinking, and the principle of differentiation. The article shows the importance of the development of these definitions of professional thinking among practising psychologists, and describes the features of the development of these definitions in group multimodal supervision. The following definitions of thinking were identified in the course of data analysis: the unity of affect and intelligence, theoretical thinking, and the principle of differentiation. These definitions productively describe what professional competencies are formed in the process of supervision by a specialist. The described competencies of professional thinking fill in the existing gap of knowledge in this area, showing how the experience of supervision in the multimodal supervision group works towards the establishment of professional identity, and what specific mental competences are developing. It is worth noting that this is the first experience of highlighting the formation of the definitions of professional thinking. The study is based on the following theoretical traditions in psychology: general psychology, psychoanalysis, and professional multimodal model of supervision.

Keywords: supervision, group multimodal supervision, professional thinking, unity of affect and intelligence, theoretical thinking, differentiation

Streszczenie Poniższa praca ma kilka celów: weryfikację wyobrażeń o „traumatycznym” charakterze superwizji, określenie potencjału superwizji w procesie rozwoju zawodowego młodych specjalistów oraz budowy i utrzymania tożsamości zawodowej wśród doświadczonych psychologów, a także omówienie rozwoju superwizji jako integralnego elementu działań praktykujących psychologów oraz innych specjalistów pracujących w zawodach pomocowych w Kazachstanie. Praca obejmuje analizę najważniejszych aspektów umiejętności profesjonalnego myślenia, którą można rozwijać w warunkach superwizji grupowej w modelu multimodalnym. Na podstawie wyników analizy wyodrębniono trzy główne zagadnienia: jedność afektu i inteligencji, myślenie teoretyczne oraz zasadę różnicowania. W pracy ukazano znaczenie tych elementów z perspektywy umiejętności profesjonalnego myślenia praktykujących psychologów oraz scharakteryzowano ich rozwój w warunkach grupowej superwizji multimodalnej. W toku analizy zebranych danych zidentyfikowano następujące zagadnienia: jedność afektu i inteligencji, myślenie teoretyczne oraz zasadę różnicowania. Pojęcia te w sposób produktywny opisują, jakie kompetencje zawodowe kształtują się w procesie superwizji z udziałem specjalisty. Opisane kompetencje wypełniają lukę w wiedzy w przedmiotowym zakresie, pokazując, w jaki sposób superwizja prowadzona w modelu multimodalnym przyczynia się do rozwoju tożsamości zawodowej oraz jakie kompetencje mentalne kształtują się w tym procesie. Warto podkreślić, że jest to pierwsze opracowanie dotyczące rozwoju zawodowego w tej grupie z uwzględnieniem podanych uwarunkowań. Opracowanie opiera się na następujących tradycjach teoretycznych w psychologii: psychologii ogólnej, psychoanalizie oraz superwizji w modelu multimodalnym.

Słowa kluczowe: superwizja, superwizja grupowa w modelu multimodalnym, umiejętność profesjonalnego myślenia, zasada jedności afektu i inteligencji, myślenie teoretyczne, różnicowanie 


\section{INTRODUCTION}

$\mathrm{T}$ he development of practical psychology and psychotherapy in Kazakhstan is spontaneous, and the training of specialists in the area of "psychology" is divorced from practical realities. At the moment, there are no institutions in Kazakhstan that provide practical training for practising psychologists within a certain modality. It is possible to complete a specialty training abroad or in the framework of professional development courses, training programmes and seminars organised within professional communities or on the personal initiative of a specialist. Specialised training of practising psychologists is carried out through the invitation of psychologists of various modalities from the USA, Europe, Russia, and Ukraine.

The term "practising psychologist" used in the article denotes a psychologist who runs a private practice, working with people who have difficulties in social adaptation or in working through certain emotions, for example grief. We cannot use the term "psychotherapist" or "clinical psychologist," since there are no such professions in the official register of professions established by the Ministry of Labour and Social Protection of the Republic of Kazakhstan. There are also great difficulties associated with the establishment and division of competencies in various branches of psychological science. At present, school psychologists, medical psychologists, and social psychologists are singled out in a separate group. Of note, after university graduation, students receive a diploma stating that they are "bachelors of social knowledge," but not "psychologists."

Undergraduate studies do not provide training in specific areas of psychology, such as "practising psychologist," "clinical psychologist," etc. Currently, there are specialised programmes in psychology at the MA level, but they are still quite new. When the term "medical psychologist" is used in Kazakhstan, it often denotes general practitioners who have completed 3-month psychology courses at the Institute for Advanced Studies, and for the most part they do not have sufficient knowledge and skills in psychology. Also, sometimes "medical psychologists" refer to specialists with a degree in psychological education who have received additional education abroad in the field of medical psychology, but due to the lack of medical education they experience problems with nostrification. The career path followed by psychologists to become professionals in various fields of psychology is very relevant, and at the state level there are a number of very formal decrees, the implementation of which requires a long and painstaking process. At the moment, professional psychological associations are only just forming (and breaking up very quickly, after $2-3$ years of existence) and are not able to independently recognise and provide professional training for psychologists. The training offered at universities is mainly theoretical and academic in nature, and graduates of psychological depart- requiring additional education within the framework of certification programmes in Russia, Ukraine, Europe or the United States.

In this context, the term "client" and "patient" are not equally relevant terms. In the article, we use the term "client," since non-pharmacological interventions are addressed.

The educational market is saturated with offers and educational programmes of various quality and certification. A massive wave of pseudo-educational programmes is observed, which negatively affects the process of training highly qualified psychological personnel. Active work is carried out within the framework of professional psychological associations, aimed at promoting the ethical standards of psychologists, upholding standards of professional training, and introducing regular supervision as a constant element of professional development and functioning of any practising psychologist. The multimodal supervision group for practising psychologists and specialists of the helping professions has been working steadily for 5 years. Currently in Kazakhstan there are 10 accredited supervisors for individual and group supervision. These supervisors have been accredited by the Professional Psychotherapeutic League (PPL) of Russia. The League is a new type of association for professionals in psychotherapy, practical and advisory psychology. PPL is the world's largest Russian-speaking professional community, bringing together members from 28 countries.

When addressing supervision, most sources indicate that supervision represents an important mandatory part of the training of practising psychologists of any modality, as well as specialists of the helping professions. The available publications on the topic of supervision focus on a number of important points:

- development of professional knowledge and skills (Harvey and Struzziero, 2008; Kovshova, 2016; Wells, 2009);

- development and preservation of professional identity (Chernyshova, 2015, 2012);

- professional development (Pyshinska, 2011; Zalevsky, 2008);

- in compliance with ethical standards, integration of personal values and ethical positions with professional ethics (Falender, 2020; Ricou and Marina, 2020; Thomas, 2014; Veselova and Korzhova, 2020; Zur, 2017).

At the same time, it should be noted that a relatively large number of psychotherapists and practising psychologists are not ready for supervision due to a number of factors. First, supervision was exceptionally frustrating and sometimes even traumatic in the initial stages of its development and emergence as a practice in Kazakhstan, which is attributable to the competitive dynamics of specialists, the lack of hours of personal therapy, and the lack of in-depth understanding of the supervisory process (the "wild" period in the development of supervision). Consequently, a number of practising psychologists, even those understanding the importance and relevance of supervision, either do not have it at all, or pass it occasionally from foreign 
experts. Secondly, supervision is a process of an evaluative nature, and a proportion of specialists feel a sense of danger to their self-respect and self-esteem, as well as the fear of losing their professional identity. Thirdly, a number of practising psychologists have a rather low level of qualifications, and do not consider it necessary to receive supervisory support.

This situation is disturbing. This article was prepared on the basis of a speech delivered at the IV Scientific-Practical Conference "Modernisation of Consciousness and Supervision: Conditions, Opportunities and Prospects." The purpose of the paper is to change the perception of the traumatic nature of supervision, to uncover its potential in the development of young specialists, to preserve and maintain professional identity among experienced psychologists, and to develop supervision as an integral part of the fullfledged activities of practising psychologists and specialists in the helping professions in Kazakhstan.

\section{METHODS}

In this study, an interpretative hermeneutic approach is applied as a general qualitative research strategy. The use of an interpretive mode of understanding allows not only to describe the problem, but also to highlight the main definitions in the development of professional thinking of practising psychologists.

The study is based on the following theoretical traditions in psychology: general psychology, psychoanalysis, group analysis, and professional multimodal model of supervision.

The selection of these definitions of thinking is associated with the analysis, synthesis, generalisation and subsequent interpretation of the material of the practical work of the multimodal supervision group, interviews with participants of the multimodal supervision group, and four scientific and practical conferences devoted to the development of supervisory practice.

A free anonymous control interview was conducted for the purpose of our study. The interview was attended by 30 specialists who, for one reason or another, left the multimodal supervision group during its operation, and 14 practising psychologists that make up the core of the group, including six accredited supervisors. The main focus of the specialists constituting the core of the supervision group included such areas as Jungian analysis, psychoanalysis, group analysis, and art therapy.

Despite the anonymity of participation, practising psychologists experienced tangible concerns about how the information they provide would be used, and whether they would be recognised. Some specialists refused to participate.

The purpose of the interview was to study issues related to the complexity of integration into the supervising group, the emotions experienced in this regard, and also to understand what skills were enhanced during participation.

\section{LITERATURE REVIEW}

In foreign psychology, the theme of the formation and development of professional skills of practising psychologists has been studied quite extensively. Various studies have been carried out, and appropriate research tools (scales, questionnaires) have been developed to study this area.

The study of psychotherapeutic and counselling skills has been conducted for many years at the Laboratory for Research in Consultative Psychology at the University of Maryland, USA (Hill and Lent, 2006; Hill et al., 1981, 2007). The studies focused on the development of professional skills during training and the holding of first consultation meetings. The researchers noted that further research needed serious methodological development.

Orlinsky and Rønnestad (2005) conducted a large-scale study of the personality of psychotherapists without bias and evaluation of psychological schools. The results of the study showed that, while experienced practising psychologists noted the importance of supervision for the development of professional thinking, young specialists highlighted that when working with difficult patients, supervision sometimes increased the levels of stress and confusion, and was frustrating. The authors emphasise that supervision should ensure and facilitate professional growth. Leonard (2015) notes that at the moment there are not enough studies that would confirm the effectiveness of supervision. According to the author, there is insufficient information about which approaches to supervision work best, and what results of the development of professional competencies occur in the process of supervision.

In Russian studies, emphasis has been placed on the development of empathy as a professionally important quality, and the advantages of various educational programmes. As noted by Kryuchkov (2015), this topic in Russian psychology is developed very poorly, especially with regard to specific empirical and experimental studies within this area. The topic of supervision is also poorly understood in Kazakhstan. Over the past few years, a small number of publications have addressed some aspects of dynamic processes in the multimodal supervision group (Igumnova, 2015; Lashkova et al., 2018; Madalieva and Igumnova, 2016; Sadykova, 2014; Sheveleva, 2016). However, the issues of the formation and development of professional thinking in the context of supervision are not adequately covered.

Thus, in practical psychology there is a situation when, on the one hand, experienced practitioners and training psychologists highlight the importance of supervision for the formation of professional identity and professional competencies, but at the same time, they cannot pinpoint exactly what kind of competencies are formed, and how the process proceeds.

\section{RESULTS AND DISCUSSION}

The aims of this article are multifaceted: to change the perception of the traumatic nature of supervision, to reveal 
its potential in the development of young specialists, to preserve and maintain professional identity among experienced psychologists, and to develop supervision as an integral part of the full-fledged activities of practising psychologists and specialists in the helping professions. To achieve this goal, it is important that practising psychologist do not experience significant difficulties with integration into the multimodal supervision group.

The results showed that $80 \%$ of specialists experienced tangible difficulties when entering a group associated with the manifestation of early narcissistic dynamics. In the supervising group, narcissistic dynamics manifests itself as follows:

- strong touchiness and fragmentation of self;

- feeling of emptiness, depression, inertness;

- permanent fear of loss of love or object;

- feeling unhappy even with productive work in a small circle;

- idealisation and depreciation.

$72 \%$ of specialists noted that the competitiveness in the group was the most difficult aspect.

Of note, the work of the multimodal group supervision is subject to the rules that divide the supervisory session into 5 stages:

1. stage 1 - introduction and selection of the supervising case, division of the group into large and small circles;

2. stage 2 - provision of the case;

3. stage 3 - asking questions;

4. stage 4 - feedback in accordance with the request of the specialist providing the case;

5. stage 5 - completion of supervision, summary of the dynamics of the group.

It is important to emphasise that the difficulties with narcissistic and competitive dynamics are experienced by both new specialists joining the group, and those who form the core of the group when new specialists come.

Quite often, new specialists come to the group unprepared, without familiarising themselves in advance with the rules of the group, which aggravates the flow of both narcissistic and competitive dynamics. To relieve this tension, before each new supervisory session, the supervisor reminds the participants about the rules of the group. However, not understanding the rules properly provides a good basis for the emergence of such feelings as touchiness, uselessness, alienation, sense of wasted time, anger, and irritation. Also, very conflicting feelings arise among the participants in association with the selection of a small circle. On the one hand, there is a desire to be selected and actively participate in supervision, but on the other hand, there is a strong fear of saying something "stupid," not understanding what is happening, and losing professional identity.

Those who form the core of the group and the appointed supervisor are very strict in monitoring compliance with the established rules and conditions of the setting, which reinforces the competitive dynamics between them and new specialists who might break the rules because of their poor understanding combined with the drive to present themselves as experienced specialists. Sometimes this leads to new specialists devaluing the whole group, or "teaching" others how to work properly. Such dynamics in the group cause a lot of stress. New specialists who join the group are not always able to cope with such levels of stress, pay attention to studying the group work rules, and separate their personal dynamics from the group dynamics and the case provided. Consequently, some new specialists are unable to integrate successfully, and leave the group.

The factors that help specialists integrate into the working multimodal supervision team were also examined during the interview. Three main factors were highlighted:

- definition of professional identity and one's place in the group through manifestation of oneself in the group asking questions, expressing feedback;

- understanding the importance of the contribution of each participant to the group - young inexperienced specialists very subtly feel the unconscious repressed emotions in the group, just like specialists from other modalities give a different perspective on how to look at the problem and understand the difficulties that arise;

- informal communication between supervisions helps to cope with the over-idealisation of more experienced specialists, to get support, explanations, and psychological help and support when joining the dynamics of a case (infection with emotions).

As the next step, an important question was asked: what definitions of professional thinking develop in the process of obtaining regular supervisory support?

During the study, three such definitions were highlighted:

1. unity of affect and intelligence;

2. theoretical thinking;

3. principle of differentiation.

The proposed definitions are discussed in greater detail below. Unity of affect and intelligence. The basis for analysing this definition was the idea proposed by Vygotsky (2005) to address the dynamic connection of affect and intelligence, the combination of which forms the worldview of wholeness, denoted by Zinchenko (1995) as the ability to bring the mind to life, which generates live personal knowledge. In their ontogenetic development, thinking and emotions originate from a single root, i.e. from the affective action of the infant. The subsequent development of the emotional sphere proceeds along two paths: along the path of differentiation of emotions, and in the direction of changing the nature of dynamic processes. This unity begins to form from the crisis of seven years and is directly related to the loss of childlike spontaneity, when a space for generalised experience appears between action and desire, for the logic of feelings, and when a child begins to think about the meanings of his behaviour for himself. There is an "intellectualisation of affect" or, in other words, emotions become "smart," and anticipating.

"Things do not change from the fact that we think them, but the affect and the functions connected with it change 
depending on the fact that they are recognised. They become differently related to consciousness and to another affect, and therefore their relation to the whole and its unity changes" (Vygotsky, 1984).

The importance of developing this definition in the supervision process is obvious. Emotions are among the working tools of any practising psychologist. This is connected both with the designation of emotions within a therapeutic session, with the interpretation of transference and countertransference in the process of psychotherapy, and with the differentiation of emotional states. In order to work with the client's psyche, it is important for a practising psychologist to have a good understanding of the information that comes from them, both in verbal and non-verbal forms, as well as to analyse their own emotional responses to the client. Such analytical dynamics make it possible to bring the mind to the senses, restoring a connection with the split aspects of the psyche and repressed emotions, returning, and sometimes forming the logic of feelings.

Supervision is necessary for every beginner practising psychologist as a didactic instrument, since there is a need for the coexistence of an emerging experience, for understanding the processes taking place during therapy, and for the possibility of withdrawing from relationships in order to better see and comprehend what is happening. In such a situation, the supervisor helps to "hold the mind" in affectively charged sessions. For experienced practising psychologists, supervision becomes a constant element of their work. Their need for supervision when working with clients can be associated not only with holding the mind into feelings, but also with conducting feelings into the mind. This is particularly relevant when working with "broken" clients, when from session to session there is a feeling of lack of feelings or a feeling that nothing happens. In such situations, it is supervision that creates "living knowledge," allowing one to find new metaphors or images that carry meaning and make the hidden processes taking place visible.

Theoretical thinking. The allocation of this definition to a separate position is not accidental, as there is an urgent need to talk about the development of theoretical thinking among practising psychologists. The main problem in this regard is that it exists only in the form of content, and not in the form of a phenomenon, an event (Zinchenko, 1995); it is impartial and dogmatic, and does not bear the imprint of a personality. This leads either to a deadly adherence to dogma, or to "rejection" of theoretical thinking in general as knowledge that has no use.

Work done in a supervisory group allows one to develop theoretical thinking by maintaining openness and understatement, as there is not only the reality associated with the presented clinical case, but there is also a subject (psychologist) who, while defining the ongoing process, creates themselves as a specialist. Supervision forms a cognitive attitude, allowing one to find the clinical confirmation of a theory, or a dogma that can sometimes be useful to a specific client rather than clients in general (Casement, 2005).
The concepts of a person, levels of functioning of the psyche, limitations and possibilities of theoretical understanding, schemes and algorithms of thinking are subject to such approbation, which leads to the formation of live psychological personal knowledge carried by the "cogital Self" (Petrovsky's term) of specialist (Petrovsky, 2014).

Principle of differentiation. The concept of differentiation emerged in association with the definitions discussed above. However, we consider it necessary to single it out as a separate item, as the problem of differential diagnosis is key in providing psychological assistance to clients. Determining the level of organisation of the psyche, the type of personality, and the prevailing defences is known to be helpful with building a psychotherapeutic hypothesis about the main causes of psychological difficulties experienced by the client, and developing a strategy for psychotherapy. Of particular interest in this regard is the study by Chuprikova (2007) and her understanding of the principle of differentiation as a universal rule for the development of systems, which works in conjunction with the principle of integration and the principle of the original whole. This understanding reflects the complexity involved in developing differential diagnosis skills. The ideas of E. Gibson, H. Werner, and C. Bridges, highlighting age-related development as a principle of differentiation, are also applicable to the formation of skills of differential diagnosis in the process of supervision. First of all, it is when the supervisor or supervisors (in a group-based form of supervision) responding to the request of a specialist (psychologist) begin to expand the analytical process of making a psychological diagnosis to the outside, exposing the essential dividing events, differentiating emotions and states, and putting together a picture of a client's life. In this case, group multimodal supervision provides more opportunities for the development of differentiation, allowing 5-8 positions of different supervisors to be implicated simultaneously, observe and live step by step, analyse the analytical situation with them, learning to actively extract from the general information flow subtler and more accurate invariants that are essential for the advancement of the psychotherapeutic hypothesis.

\section{CONCLUSION}

Group multimodal supervision serves as a kind of "laboratory practice" for a novice specialist, whereas for an experienced psychologist, the supervisory group becomes an instrument that enhances the sensitivity, reflexivity, and dialectical unity of differentiation and integration of theoretical concepts, so that they can be correlated with the real life history of the client.

Several definitions of thinking were identified in the course of data analysis: unity of affect and intelligence, theoretical thinking, and principle of differentiation. These definitions productively describe what professional competencies are formed in the process of supervision by a specialist. 
The described competencies of professional thinking fill in the existing gap of knowledge in this area, showing how the experience of supervision in the multimodal supervision group contributes to the establishment of professional identity, and what specific mental competences are developing. It is worth noting that this is the first experience of highlighting the formation of the definitions of professional thinking. We assume that there are also other categories of professional thinking that develop in the process of supervision, and they need to be identified and understood as well. The study highlights the main difficulties involved in the integration into a supervisory group, such as narcissistic and competitive dynamics, and compliance with the rules of the group.

The factors that contribute to the integration of new psychologists in their supervision group were also identified in the study. These factors include: determining professional identity and one's place in the group through self-expression; understanding the importance of each participant's contribution to the group; and informal communication between supervisors.

Summarising the above, we note a range of definite advantages associated with participating in regular group supervision, including:

1. Group multimodal supervision serves as a laboratory of the mind, within the framework of which it is possible by observing the work of experienced specialists - to learn the skills of differentiation, and integration of the affective and intellectual spheres, and to test and develop theoretical ideas.

2. Group multimodal supervision provides a multiplicity of mirrors and identifications, which contributes to the development of a unique way of work for each psychologist, and reduces the risk of borrowing too directly from the supervisor's way of working with clients.

3. The diversity of opinions characteristic of group multimodal supervision allows the algorithms and thinking patterns to be expanded, thereby preserving the living personal psychological knowledge and cognitive attitude of the psychologist.

\section{Conflict of interest}

The authors do not report any financial or personal connections with other persons or organisations which might negatively affect the contents of this publication and/or claim authorship rights to this publication.

\section{References}

Casement P: [Education from the Patient (part 1-2)]. Daryn, Almaty 2005. Chernyshova LA: [The role of clinical supervision in preparing students of the Faculty of Medical Psychology for successful professional activity]. News Samara Sc Center Rus Acad Sc 2015; 17: 371-373.

Chernyshova LA: [Role of supervision in the formation of professionally important qualities of the clinical psychologist]. News Samara Sc Center Rus Acad Sc 2012: 14: 175-179.
Chuprikova NI: [Mental Development: The Principle of Differentiation]. Peter, Saint Petersburg 2007.

Falender CA: Ethics of clinical supervision: an international lens. Psychology in Russia: State of the Art 2020; 13: 42-53.

Harvey VS, Struzziero JA: Professional Development and Supervision of School Psychologists. From Intern to Expert. Corwin Press, Thousand Oaks 2008.

Hill CE, Lent RW: A narrative and meta-analytic review of helping skills training: time to revive a dormant area of inquiry. Psychotherapy (Chic) 2006; 43: 154-172.

Hill CE, Charles C, Reed KG: A longitudinal analysis of changes in counseling skills during doctoral training in counseling psychology. J Couns Psychol 1981; 28: 428-436.

Hill CE, Stahl J, Roffman M: Training novice psychotherapists: helping skills and beyond. Psychotherapy (Chic) 2007; 44: 364-370.

Igumnova OV: [Manifestation of splitting the interpretation of dynamic processes in multimodal group supervision. Man in an era of change]. The challenges of the present, building the future. Proceedings of the IV Congress of the therapists, psychiatrists, psychologists and consultants of the Siberian Federal District, 2015.

Kovshova OS: The Samara school of psychological supervision. Med Psychol Ross 2016; 8 (5): 5.

Kryuchkov KS: [Counseling psychology and psychotherapy skills' studies: current status in Western and Russian psychology]. Journal of Modern Foreign Psychology 2015; 4: 76-87.

Lashkova Y, Berdibayeva S, Beissenova Z et al.: The phenomenon of "disappearances" in the process of supervision in a permanent professional multimodal supervision group. Psychiatr Psychol Klin 2018; 18: $35-40$.

Leonard E: Unscrambling supervision. InPsych 2015; 37 (6). Available from: https://www.psychology.org.au/inpsych/2015/december/ leonard.

Madalieva ZB, Igumnova OV: [The manifestation of splitting the interpretation of dynamic processes in the multimodal group supervision]. Bull of KNU 2016; 1 (56): 67-71.

Orlinsky DE, Rønnestad MH: How Psychotherapists Develop: A Study of Therapeutic Work and Professional Growth. American Psychological Association, Washington 2005.

Petrovsky VA: [Self: the configuration of artifact]. Cultural-Historical Psychology 2014; 10 (1): 63-78.

Pyshinska IV: [Notes on didactic supervision]. Counseling Psychology and Psychotherapy 2011; 19 (4): 51-57.

Ricou M, Marina S: Decision making and ethical reasoning in psychology. Psychology in Russia: State of the Art 2020; 13: 2-10.

Sadykova AZh: [Dynamic group processes in the work of a supervisory group]. Smalta 2014; 2: 47-53.

Sheveleva EV: [Internal and external borders in supervisory ethics]. J Pract Psychologist 2016; 4: 171-179.

Thomas JT: International ethics for psychotherapy supervisors: principles, practices, and future directions. In: Watkins CE, Milne DL (eds.): The Wiley International Handbook of Clinical Supervision. Wiley Blackwell, 2014: 131-154.

Veselova EK, Korzhova EYu: Ethical and moral levels in the functioning of the personality of the educational psychologist. Psychology in Russia: State of the Art 2020; 13: 22-32.

Vygotsky LS: [Psychology of Human Development]. Publishing House Meaning, Moscow 2005.

Vygotsky LS: [The Collected Works in 6 Volumes. Volume 5]. Pedagogy, Moscow 1984.

Wells BJ: Perceptions of School Psychology Supervisors and Practitioners about Supervision Practices in the Southeastern Region of the US: An Exploratory Study Using Concept Mapping. Dissertation, Georgia State University, 2009.

Zalevsky GV: [Supervision: practice in search of theory]. Siber Psychol J 2008; 30: 7-13.

Zinchenko VP: [Affect and Intelligence in Education]. Trivola, Moscow 1995.

Zur O (ed.): Multiple Relationships in Psychotherapy and Counseling: Unavoidable, Common, and Mandatory Dual Relationships in Therapy. Routledge, New York 2017. 